\title{
Catalytic conversion of lignin in woody biomass into phenolic monomers in methanol/water mixtures without external hydrogen
}

\section{Citation for published version (APA):}

Ouyang, X., Huang, X., Zhu, J., Boot, M., \& Hensen, E. (2019). Catalytic conversion of lignin in woody biomass into phenolic monomers in methanol/water mixtures without external hydrogen. ACS Sustainable Chemistry \& Engineering, 7(16), 13764-13773. https://doi.org/10.1021/acssuschemeng.9b01497

DOI:

10.1021/acssuschemeng.9b01497

Document status and date:

Published: 19/08/2019

\section{Document Version:}

Publisher's PDF, also known as Version of Record (includes final page, issue and volume numbers)

\section{Please check the document version of this publication:}

- A submitted manuscript is the version of the article upon submission and before peer-review. There can be important differences between the submitted version and the official published version of record. People interested in the research are advised to contact the author for the final version of the publication, or visit the DOI to the publisher's website.

- The final author version and the galley proof are versions of the publication after peer review.

- The final published version features the final layout of the paper including the volume, issue and page numbers.

Link to publication

\footnotetext{
General rights

- You may freely distribute the URL identifying the publication in the public portal. follow below link for the End User Agreement:

www.tue.nl/taverne

\section{Take down policy}

If you believe that this document breaches copyright please contact us at:

openaccess@tue.nl

providing details and we will investigate your claim.
}

Copyright and moral rights for the publications made accessible in the public portal are retained by the authors and/or other copyright owners and it is a condition of accessing publications that users recognise and abide by the legal requirements associated with these rights.

- Users may download and print one copy of any publication from the public portal for the purpose of private study or research.

- You may not further distribute the material or use it for any profit-making activity or commercial gain

If the publication is distributed under the terms of Article $25 \mathrm{fa}$ of the Dutch Copyright Act, indicated by the "Taverne" license above, please 


\title{
Catalytic Conversion of Lignin in Woody Biomass into Phenolic Monomers in Methanol/Water Mixtures without External Hydrogen
}

\author{
Xianhong Ouyang, ${ }^{\dagger}$ Xiaoming Huang, ${ }^{* \dagger}{ }^{\dagger}$ Jiadong Zhu, ${ }^{\dagger}$ Michael D. Boot, ${ }^{\ddagger}$ and Emiel J. M. Hensen* ${ }^{* \dagger \oplus}$ \\ ${ }^{\dagger}$ Institute of Catalysis, Laboratory of Inorganic Materials \& Catalysis and ${ }^{\ddagger}$ Combustion Technology, Department of Mechanical \\ Engineering, Eindhoven University of Technology, P.O. Box 513, 5600 MB Eindhoven, The Netherlands
}

\section{Supporting Information}

\begin{abstract}
The valorization of lignin in renewable lignocellulosic biomass is an important target in the transition to a more sustainable production of fuels and chemicals. We present here a modification of the "lignin-first" approach that does not hinge on the use of external hydrogen. Instead, we use methanol/water mixtures as a suitable solvent that can be partly reformed into hydrogen. We propose a one-step process in which in planta lignin (wood sawdust) is converted to phenolic monomers over a Ptbased catalyst in an inert atmosphere. The role of the methanol/water mixture is not only to supply hydrogen but also to extract lignin fragments from the biomass matrix. Pt catalyzes methanol reforming to obtain hydrogen and the stabilization of reactive lignin intermediates by hydrogenation of reactive bonds. The latter aspect is crucial to avoid unfavorable condensation of fragments. Under optimized conditions, a yield of phenolic monomers of nearly $50 \%$ can be obtained from birch wood at a temperature of $230{ }^{\circ} \mathrm{C}$ in $3 \mathrm{~h}$.
\end{abstract}

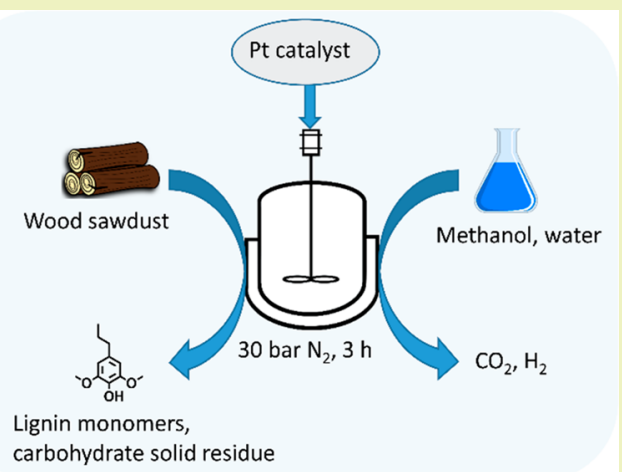

KEYWORDS: Lignin, Aromatics, Lignin first, Hydrogen, Reforming, Catalysis

\section{INTRODUCTION}

Nearly all fuels and bulk and specialty chemicals are currently produced from fossil resources. ${ }^{1}$ This practice cannot be sustained due to the negative impact on the environment of the use of nonrenewable feedstocks with global warming as the greatest concern. Replacing petroleum feedstock by nonfood lignocellulosic biomass is widely considered as a promising alternative for the production of chemical building blocks in a sustainable manner. ${ }^{2}$ The main components contained in lignocellulose are cellulose, hemicellulose, and lignin. Cellulose and hemicellulose are polymers of carbohydrates, while lignin is made up from the phenylpropanoids $p$-hydroxyphenyl $(\mathrm{H})$, guaiacyl $(\mathrm{G})$, and syringyl $(\mathrm{S})$ derived from the respective monolignols $p$-coumaryl alcohol, coniferyl alcohol, and sinapyl alcohol. $^{3}$ Efficient fractionation of these three main components of lignocellulose is important when the aim is to obtain value-added products of the monomers contained in them.

While many processes have been developed to convert the carbohydrate fractions of woody biomass into useful intermediate chemicals, ${ }^{4}$ the upgrading of lignin is at a much more infant stage. It is however increasingly recognized that lignin is a very interesting source of sustainable aromatics. ${ }^{5}$ Moreover, biorefining concepts that traditionally focus on sugar upgrading can only be cost competitive when as much as possible of the lignocellulosic biomass is valorized. ${ }^{6}$ Accordingly, many researchers have explored possibilities to convert lignin into aromatic monomers. ${ }^{7-10}$ An important corollary of these investigations so far is that technical lignins, which are obtained by first removing the cellulose part from woody biomass, are very unreactive. The main cause is that most of the reactive ether-type lignin intralinkages in the original woody biomass have been condensed into more recalcitrant carbon-carbon bonds. ${ }^{7}$ This explains the attractiveness of "in planta" fractionation of lignin as compared to the valorization of "ex planta" (technical) lignin. Selective removal of lignin fragments can be achieved under much milder conditions by reductive depolymerization of the original woody biomass than by upgrading of lignin. ${ }^{11}$ In the in planta approach the ester and ether bonds between the lignin and hemicellulose can be cleaved by solvolysis, releasing lignin oligomers. ${ }^{12}$ These reactive lignin fragments can be stabilized and converted to more stable aromatic monomers by reductive depolymerization using metal catalysis and hydrogen. ${ }^{13}$ These lignin-first approaches typically yield about 50\% aromatic monomers from the lignin fraction of woody biomass. ${ }^{14}$ Reductive lignin depolymerization comprises the extraction of lignin fragments from biomass followed depolymerization into phenolic monomers in a one-pot approach. ${ }^{11}$ A wide range of solvents has been evaluated with the aim to optimize the delignification step. ${ }^{15}$ As lignin contains both nonpolar and polar moieties, solvents with intermediate polarity such as methanol and ethanol are preferred for lignin extraction. ${ }^{16}$ The dissolved

Received: March 17, 2019

Revised: July 14, 2019

Published: July 23, 2019 
Table 1. Comparison of Different Approaches for Reductive Lignin Depolymerization Involving Hydrogen-Donor Solvents and Methanol/Water Mixtures $24,26,28$

\begin{tabular}{|c|c|c|c|c|}
\hline & $\operatorname{Ref}^{24}$ & $\operatorname{Ref}^{26}$ & $\operatorname{Ref}^{28}$ & This work \\
\hline Feedstock & $0.2 \mathrm{~g}$ of birch sawdust & $\begin{array}{l}2.0 \mathrm{~g} \text { of birch } \\
\text { sawdust }\end{array}$ & $\begin{array}{l}2.0 \mathrm{~g} \text { of poplar } \\
\text { sawdust }\end{array}$ & $\begin{array}{l}2.0 \text { of birch } \\
\text { sawdust }\end{array}$ \\
\hline Catalyst & $\begin{array}{l}30 \mathrm{mg} 1 \mathrm{~mol} \% \mathrm{Co} \text { on } \\
\text { phenanthroline/carbon }\end{array}$ & $\begin{array}{l}100 \mathrm{mg} \text { of } \\
10 \mathrm{wt} \% \mathrm{Ni} / \mathrm{C}\end{array}$ & $200 \mathrm{mg}$ of $\mathrm{Pd} / \mathrm{C}$ & $\begin{array}{l}500 \quad \mathrm{mg} \quad 1 \quad \mathrm{wt} \% \\
\mathrm{Pt} / \gamma-\mathrm{Al}_{2} \mathrm{O}_{3}\end{array}$ \\
\hline \multirow[t]{5}{*}{$\begin{array}{l}\text { Monomer } \\
\text { yield }\end{array}$} & & & & \\
\hline & $15 \mathrm{wt} \%$ & $48 w t \%$ & $35.5 \mathrm{wt} \%$ & $46.1 \mathrm{wt} \%$ \\
\hline & $11 \mathrm{wt} \%$ & $0.5 \mathrm{wt} \%$ & $5.0 \mathrm{wt} \%$ & $0.3 \mathrm{wt} \%$ \\
\hline & Others & Others & Others & Others \\
\hline & $8 \mathrm{wt} \%$ & $5.4 \mathrm{wt}^{\%} \%$ & $2.9 \mathrm{wt} \%$ & $3.1 \mathrm{wt} \%$ \\
\hline Pressure $^{a}$ & - & 1 bar Ar & $20{\text { bar } \mathrm{H}_{2}}$ & 30 bar $\mathrm{N}_{2}$ \\
\hline Temperature & $200^{\circ} \mathrm{C}$ & $200^{\circ} \mathrm{C}$ & $200^{\circ} \mathrm{C}$ & $230{ }^{\circ} \mathrm{C}$ \\
\hline Solvent & $\begin{array}{l}6 \mathrm{ml} \text { ethanol/water } \\
(1 / 1, \mathrm{v} / \mathrm{v})\end{array}$ & Pure methanol & $\begin{array}{l}40 \mathrm{ml} \\
\text { methanol/water } \\
(7 / 3, \mathrm{v} / \mathrm{v})\end{array}$ & $\begin{array}{l}40 \mathrm{ml} \\
\text { methanol/water } \\
(1 / 2, \mathrm{~mol} / \mathrm{mol})^{\mathrm{b}}\end{array}$ \\
\hline $\mathrm{H}_{2}$ source & $\begin{array}{l}\text { Formic acid and } \\
\text { sodium formate }\end{array}$ & Methanol & External $\mathrm{H}_{2}$ & $\begin{array}{l}\text { Methanol and } \\
\text { water }\end{array}$ \\
\hline $\begin{array}{l}\text { Influence of } \\
\text { water } \\
\text { addition }\end{array}$ & $\begin{array}{l}\text { Improving } \\
\text { delignification }\end{array}$ & $\begin{array}{l}\text { Decreasing } \\
\text { monomer yield }\end{array}$ & $\begin{array}{l}\text { Increasing } \\
\text { solubilization } \\
\text { lignin and } \\
\text { hemicellulose }\end{array}$ & $\begin{array}{l}\text { Improving } \\
\text { hydrogen } \\
\text { generation and } \\
\text { delignification }\end{array}$ \\
\hline $\begin{array}{l}\text { Carbohydrate } \\
\text { retention }\end{array}$ & $\begin{array}{lr}\text { Glucans } \quad 58 & \text { wt } \% \\
\text { Xylans } 4 & \text { wt } \%\end{array}$ & - & $\begin{array}{l}\text { Cellulose }{ }^{c}>90 \\
\text { wt } \% \\
\text { Hemicellulose }{ }^{d} \\
>60 \mathrm{wt} \%\end{array}$ & $\begin{array}{l}\text { Glucans } 41 \text { wt } \% \\
\text { Xylans }<1 \mathrm{wt} \%\end{array}$ \\
\hline
\end{tabular}

${ }^{a}$ Pressure at room temperature. ${ }^{b}$ Methanol/water is $10 / 9(\mathrm{v} / \mathrm{v}) .{ }^{c}$ Cellulose fraction: glucose. ${ }^{d}$ Hemicellulose fraction: xylose, arabinose, galactose, mannose.

lignin fragments are converted to phenolic monomers through metal-catalyzed hydrogenolysis in the presence of hydrogen. ${ }^{17}$ For instance, a hydrogen pressure of 30 bar was used to convert lignin in birch wood to a range of phenolic monomers using a $\mathrm{Ru} / \mathrm{C}$ catalyst. ${ }^{18}$ Delignification and lignin depolymerization can also be performed in a two-stage fixed-bed reactor, 
which allows independent control of lignin extraction and hydrogenolysis, the kinetic studies of each step, and facile separation of the heterogeneous catalyst. ${ }^{19,20}$ Lignin in poplar wood was extracted by methanol in the first bed and converted into phenolic monomers ( $18 \%$ yield) using $\mathrm{Ni} / \mathrm{C}$ in the presence of $6 \mathrm{MPa}$ hydrogen. ${ }^{19}$ Hydrogen is currently mainly produced from the steam reforming of natural gas. ${ }^{21}$ In a more sustainable scenario, hydrogen should be obtained from alternative sources. The aqueous-phase reforming of biomassderived alcohols can provide a source of hydrogen. ${ }^{22}$ Another approach is to use hydrogen-donor solvents that can later be rehydrogenated. In the context of lignin upgrading, Rinaldi et al. described a catalytic hydrogen transfer strategy in which the isopropanol solvent was converted to acetone and hydrogen in the presence of a Raney Ni catalyst. The obtained lignin oil is a complex mixture of aromatics and other low molecular weight products. The hydrogenation of acetone byproduct to isopropanol is required to recycle the solvent. ${ }^{23}$ Samec et al. used a heterogeneous cobalt catalyst for lignin depolymerization and hydrogen transfer hydrogenolysis using formic acid/ formate as a hydrogen donor in a mixture of ethanol and water, producing 34\% monophenolic compounds based on the initial lignin content. ${ }^{24}$ Moreover, hemicellulose released from birch wood was used as hydrogen donor for hydrogenolysis of lignin, and in this way, a $37 \%$ yield of phenolic monomer was obtained in a continuous-flow system. ${ }^{25} \mathrm{Xu}$ et al. reported that pure methanol can be a source of hydrogen during depolymerization of lignin: high yields (54\%) of propylguaiacol and propylsyringol were obtained using a Ni-based catalyst during the conversion of birch wood. An interesting phenomenon observed was that the lignin monomer yield dropped to $22 \%$ when water was added to the reaction. ${ }^{26}$ Besides in planta lignin conversion, a similar hydrogen-free strategy has also been used for valorization of technical lignin. Weckhuysen and coauthors reported a two-step method in which kraft, organosolv, and sugar cane bagasse lignins were dissolved in an ethanol/water mixture in the first step followed by the liquid-phase reforming of dissolved lignin to monoaromatics ( $17 \%$ yield) over a $\mathrm{Pt} / \mathrm{Al}_{2} \mathrm{O}_{3}$ catalyst in a $\mathrm{He}$ atmosphere, which helped generate hydrogen in the second step. $^{2}$

Inspired by previous work on lignin depolymerization without external hydrogen, here we present for the first time an alternative catalytic approach that combines in planta lignin depolymerization with methanol reforming using a commercial $\mathrm{Pt} / \gamma-\mathrm{Al}_{2} \mathrm{O}_{3}$ catalyst. $^{23,24,26,27} \mathrm{~A}$ comparison is made in Table 1 to emphasize the results of this work. The use of $\mathrm{Pt}$ as a catalyst not only stabilizes lignin monomers but also contributes to the hydrogen generation through the methanol reforming reaction $\left(\mathrm{CH}_{3} \mathrm{OH}+\mathrm{H}_{2} \mathrm{O} \rightarrow \mathrm{CO}_{2}+3 \mathrm{H}_{2}\right)$. The use of methanol/water mixtures has several advantages over other hydrogen-donor solvent strategies: addition of water to pure organic solvent decreases the economic cost, unsaturated byproducts such as acetone in isopropanol transfer hydrogenation are avoided, water enhances the hydrogen generation and also the extraction efficiency of lignin fragments from the lignocellulosic matrix. We found that the type of aromatic monomers can be controlled between 4-propenyl-syringol and 4-propyl-syringol by adjusting the methanol/water ratio and the reaction temperature. Up to $49 \%$ of phenolic monomers with $82 \%$ selectivity to 4-propyl-syringol can be obtained from birch wood lignin under optimized conditions (methanolwater molar ratio $1 / 2,230{ }^{\circ} \mathrm{C}, 30$ bar $\mathrm{N}_{2}, 3 \mathrm{~h}$ ).

\section{EXPERIMENTAL SECTION}

Chemicals and Materials. Birch wood sawdust was obtained from Staatsbosbeheer in The Netherlands. Anhydrous methanol, $\mathrm{H}_{2} \mathrm{SO}_{4}$ (95-97\%), ethyl acetate, tetrahydrofuran (THF), and $d_{6}$ DMSO (dimethyl sulfoxide) were purchased from Merck. nDodecane was purchased from Alfa Aesar. Guaiacylglycerol- $\beta$-guaiacyl ether and 4- $n$-propanol-guaiacol were purchased from TCI. One weight percent $\mathrm{Pt} / \gamma-\mathrm{Al}_{2} \mathrm{O}_{3}, 5$ wt \% $\mathrm{Pt} / \mathrm{C}$, and 5 wt \% $\mathrm{Pd} / \mathrm{C}$ catalysts were purchased from Sigma-Aldrich. The preparation of $\mathrm{Mo}_{2} \mathrm{C} / \mathrm{AC}$ $\left(\mathrm{AC}=\right.$ activated carbon), $\mathrm{Cu} / \mathrm{CeO}_{2}$, and $\mathrm{Cu} / \mathrm{ZnO} / \mathrm{Al}_{2} \mathrm{O}_{3}$ catalysts is given in the Supporting Information (Supporting Information section 1.2).

Feedstock Pretreatment. The birch wood sawdust was milled and sieved to a particle size of $125-300 \mu \mathrm{m}$ and pretreated to remove extractives with water $(24 \mathrm{~h})$ and ethanol $(24 \mathrm{~h})$ in a Soxhlet extractor. The pretreated birch sawdust was dried at $105{ }^{\circ} \mathrm{C}$ overnight. A standard two-step hydrolysis procedure in sulfuric acid was used to determine the Klason lignin content in birch wood (Supporting Information section 2.1). ${ }^{29}$

Catalytic Activity Measurements. In a typical reaction, $2.0 \mathrm{~g}$ of pretreated birch sawdust (20.1 wt \% Klason lignin), $500 \mathrm{mg}$ of $1 \mathrm{wt} \%$ $\mathrm{Pt} / \gamma-\mathrm{Al}_{2} \mathrm{O}_{3}$, and $40 \mathrm{~mL}$ of solvent were loaded into a $100 \mathrm{~mL}$ Parr autoclave. The autoclave was sealed and flushed with nitrogen. After leak testing, the autoclave was pressurized to $30 \mathrm{bar}$ with nitrogen at room temperature. The mixture was stirred at $500 \mathrm{rpm}$ and heated to the reaction temperature at a rate of $10{ }^{\circ} \mathrm{C} / \mathrm{min}$. After reaction, the autoclave was cooled in ice water. For the model compound experiments, $50 \mathrm{mg}$ of guaiacylglycerol- $\beta$-guaiacyl ether, $20 \mathrm{~mL}$ of methanol/water solvent, and $50 \mathrm{mg}$ of $\mathrm{Pt} / \gamma-\mathrm{Al}_{2} \mathrm{O}_{3}$ was loaded in a Parr autoclave $(100 \mathrm{~mL})$. After sealing and leak check, the autoclave was heated to the reaction temperature for $3 \mathrm{~h}$. After reaction, the monomers were extracted by ethyl acetate and analyzed by the procedures below.

Product Analysis and Characterization. The lignin products were separated from the solid residue by filtration. Methanol was removed from the filtrate by rotary evaporation. The lignin oil was extracted by $40 \mathrm{~mL}$ of ethyl acetate, and the sugar-derived products were kept in the water phase. To this end, $30 \mu \mathrm{L}$ of $n$-dodecane was added as an external standard to the lignin ethyl acetate solution to determine the lignin monomer yield. The lignin monomers were analyzed by a Shimadzu 2010 gas chromatograph with mass spectrometry and flame ionization detection equipped with a TRX1701 column. The degree of delignification was determined by the weight of lignin oil after the evaporation of ethyl acetate. ${ }^{18}$ The delignification degree and lignin monomer yield were calculated as follows:

$$
\begin{aligned}
& \text { delignification degree }(\%) \\
& =\frac{\text { weight of lignin oil }}{\text { weight of sawdust } \times \text { Klason lignin content }} \times 100 \%
\end{aligned}
$$

$$
\begin{aligned}
& \text { lignin monomer yield }(\%) \\
& =\frac{\text { weight of lignin monomers }}{\text { weight of sawdust } \times \text { Klason lignin content }} \times 100 \%
\end{aligned}
$$

The lignin oil was dissolved in THF $\left(2 \mathrm{mg} \mathrm{mL}^{-1}\right)$ and $d_{6}$-DMSO (100 $\mathrm{mg} \mathrm{mL}$ ) for gel permeation chromatography and $2 \mathrm{D}{ }^{1} \mathrm{H}-{ }^{13} \mathrm{C}$ heteronuclear single-quantum coherence (HSQC) NMR analysis. Gel permeation chromatography analysis was performed on a Shimadzu apparatus equipped with a Mixed-C and Mixed-D columns in series and a UV-vis detector operated at $254 \mathrm{~nm}$. The molecular weight was determined at $25{ }^{\circ} \mathrm{C}$ using THF as the eluent at a flow rate of 1 $\mathrm{mL} \mathrm{min}^{-1}$. 2D HSQC NMR spectra were recorded on a Bruker 400 $\mathrm{MHz}$ spectrometer. The spectral widths were 5000 and $20000 \mathrm{~Hz}$ for the ${ }^{1} \mathrm{H}$ and ${ }^{13} \mathrm{C}$ dimensions. A total of 16 scans with a $2 \mathrm{~s}$ relaxation delay and 256 time increments were used in the ${ }^{13} \mathrm{C}$ dimension. Data processing was performed by the MestReNova software. The gaseous products were collected by a gas sample cylinder and then analyzed by 
(a)
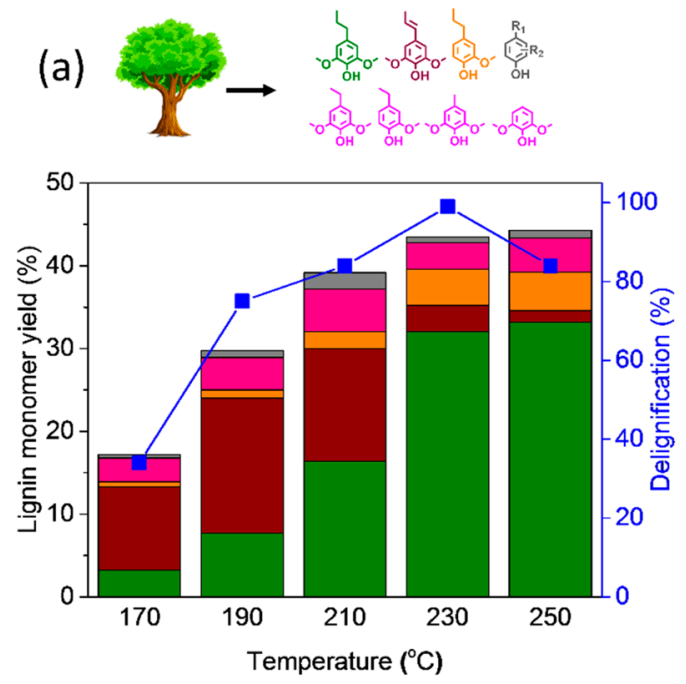

(b) $\mathrm{CH}_{3} \mathrm{OH}+\mathrm{H}_{2} \mathrm{O} \rightarrow \mathrm{CO}_{2}+\mathrm{CO}+\mathrm{H}_{2}$

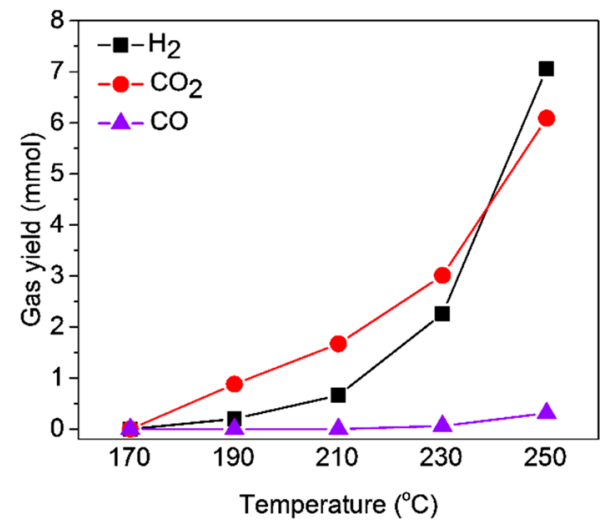

Figure 1. Influence of temperature on (a) monomer yield and delignification degree and (b) $\mathrm{H}_{2}$ generation in the birch wood lignin conversion. Reaction conditions: $2.0 \mathrm{~g}$ of pretreated birch wood (Klason lignin content $20.1 \mathrm{wt} \%$ ), $500 \mathrm{mg}$ of $1 \mathrm{wt} \% \mathrm{Pt} / \gamma-\mathrm{Al}_{2} \mathrm{O}_{3}, 40 \mathrm{~mL}$ of methanol/water mixture (molar ratio 1), 30 bar $\mathrm{N}_{2}$ at room temperature, $3 \mathrm{~h}$.

an Interscience Compact gas chromatograph equipped with Molsieve $5 \AA$ and Porabond $\mathrm{Q}$ columns connected to thermal conductivity detectors and an $\mathrm{Al}_{2} \mathrm{O}_{3} / \mathrm{KCl}$ column equipped with a flame ionization detector.

\section{RESULTS AND DISCUSSION}

We investigated the approach to use methanol/water mixtures in a nitrogen atmosphere of 30 bar by comparing different reaction temperatures, methanol/water ratios, and catalysts. Optimization of the reaction temperature and solvent composition was carried out using a commercial $\mathrm{Pt} / \gamma-\mathrm{Al}_{2} \mathrm{O}_{3}$ catalyst with a metal loading of 1 wt \%. Such supported $\mathrm{Pt}$ catalysts are known to be active for aqueous phase reforming of alcohols and carbohydrates and also the valorization of organosolv lignin. ${ }^{27,30,31}$ Although $\gamma-\mathrm{Al}_{2} \mathrm{O}_{3}$ is not stable under hydrothermal conditions, it has been shown that the interaction with lignin fragments can slow down the conversion to boehmite. ${ }^{32}$ We studied the mechanism in more detail by using guaiacylglycerol- $\beta$-guaiacyl ether as a model compound. Finally, we discuss the benefits of our approach and the implications for aromatics production from lignocellulosic biomass.

Influence of Temperature. Catalytic upgrading of birch wood was carried out in methanol/water mixtures under a nitrogen atmosphere using $\mathrm{Pt} / \gamma-\mathrm{Al}_{2} \mathrm{O}_{3}$ as a catalyst. In our approach, the catalyst is involved in the depolymerization of lignin, reforming of methanol to produce hydrogen, and possibly in the extraction of lignin from the biomass matrix. Reductive lignin-first processes are typically performed in the 170-250 ${ }^{\circ} \mathrm{C}$ temperature range, depending on the heterogeneous catalyst, addition of cocatalysts, solvent, and biomass resource. $^{33}$ The aqueous reforming of light alcohols occurs at $150-350{ }^{\circ} \mathrm{C} .^{34}$

Figure 1a shows the delignification degree and lignin monomer yield in an equimolar mixture of methanol and water after a reaction time of $3 \mathrm{~h}$. The delignification degree becomes higher with increasing temperature. At $210^{\circ} \mathrm{C}$, about $84 \%$ of lignin is removed from birch wood sawdust and $98 \%$ of cellulose remains intact in the carbohydrate residue. Only $17 \%$ of hemicellulose was left, the ease of degradation being due to its amorphous structure, which allows for easy contact with the reagents. Analysis of sugar-derived products revealed that part of hemicellulose was converted to xylose (7.0 wt \%), ethylene glycol (1.3 wt \%), 1,2-propanediol (1.2 wt \%), and 1,2butanediol (1.0 wt \%) (Table S1). Under the present conditions we also expect the formation of humins due to the xylose oligomerization. ${ }^{35}$ The birch wood mass balance after reaction at $210{ }^{\circ} \mathrm{C}$ is $83 \%$ (Table S2). The highest delignification degree (99\%) is observed at $230{ }^{\circ} \mathrm{C}$. However, carbohydrate retention in the obtained solid residue decreases with increasing temperature (Figure S1). The lignin monomers obtained in these experiments are mainly 4-propyl-guaiacol, 4propenyl-syringol, and 4-propyl-syringol. While lignin monomer yield is only $17 \%$ at $170{ }^{\circ} \mathrm{C}$, it increases to $43 \%$ at $230{ }^{\circ} \mathrm{C}$. The delignification degree at $250^{\circ} \mathrm{C}$ is substantially lower than that at the optimum temperature of $230{ }^{\circ} \mathrm{C}$. The product distribution depends strongly on the reaction temperature. At low temperature the main products were syringol-derived monomers, while the selectivity to guaiacol-derived monomers increases at higher temperature. The lignin part of birch wood, which is a hardwood, contains mainly syringyl (S) units and a relatively small amount of guaiacyl (G) units. $^{33}$ Thus, our results show that the extraction and depolymerization of S-type lignin fragments is easier than those of G-type lignin fragments. While 4-propenyl-syringol was the main product at $170^{\circ} \mathrm{C}$, the double bond in the side chain was increasingly hydrogenated with increasing temperature. Samec et al. also reported that the monomer selectivity in lignin conversion toward the unsaturated product (4-propenyl-syringol) can be increased by using hemicellulose as the hydrogen donor using a $\mathrm{Pd} / \mathrm{C}$ catalyst. ${ }^{36}$ At $230{ }^{\circ} \mathrm{C}$, 4-propyl-syringol was the main product in the lignin oil. We attribute this to the higher partial pressure of hydrogen with increasing temperature as a result of more extensive methanol reforming. To verify this hypothesis, we also analyzed the gas-phase products in these experiments (Figure 1b). The main components in the gas phase were hydrogen, carbon monoxide, and carbon dioxide. A small amount of hydrocarbons, mostly methane, was obtained as a byproduct (Figures S2 and S3). Figure 1 b confirms that the hydrogen yield increases with temperature due to increased methanol reforming, thus providing a good explanation for the 
(a)
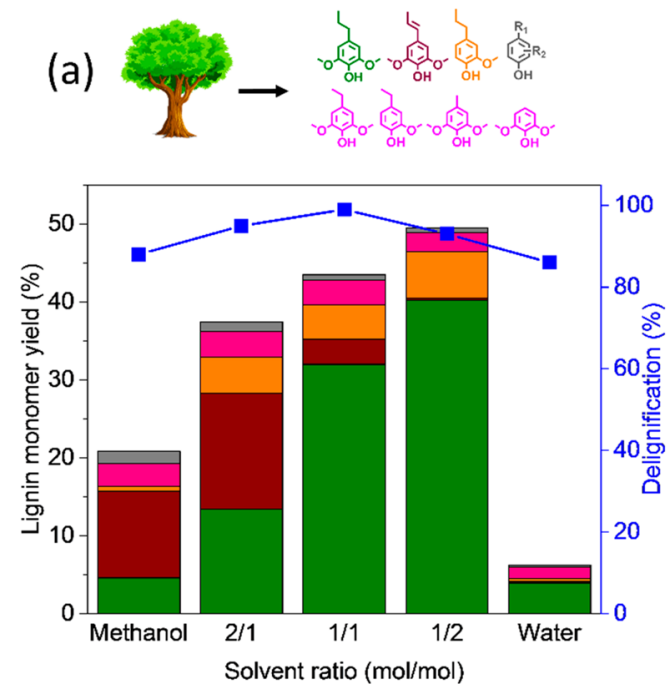

(b) $\mathrm{CH}_{3} \mathrm{OH}+\mathrm{H}_{2} \mathrm{O} \rightarrow \mathrm{CO}_{2}+\mathrm{CO}+\mathrm{H}_{2}$

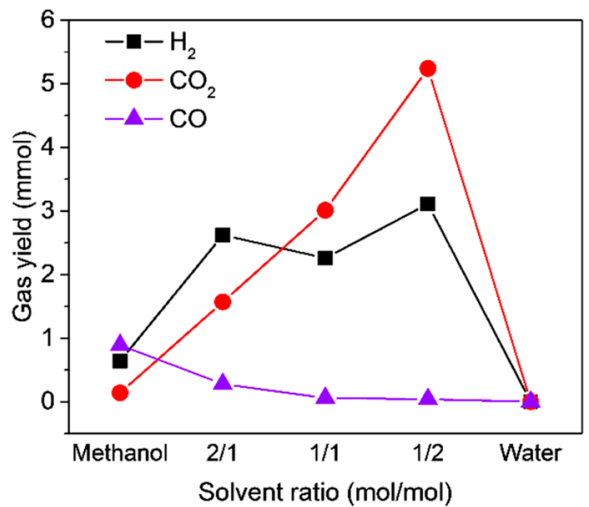

Figure 2. Influence of methanol/water ratio on (a) monomer yield and delignification degree and (b) $\mathrm{H}_{2}$ generation in the birch wood lignin conversion. Reaction conditions: $2.0 \mathrm{~g}$ of pretreated birch wood (Klason lignin content $20.1 \mathrm{wt} \%$ ), $500 \mathrm{mg}$ of $1 \mathrm{wt} \% \mathrm{Pt} / \gamma-\mathrm{Al}_{2} \mathrm{O}_{3}, 40 \mathrm{~mL}$ of solvent, 30 bar $\mathrm{N}_{2}$ at room temperature, $230{ }^{\circ} \mathrm{C}, 3 \mathrm{~h}$.

increased rate of double-bond hydrogenation. Moreover, the product distribution of methanol reforming indicates that the rehydrogenation of solvent-derived byproduct is not necessary compared with a previous hydrogen transfer strategy, which uses isopropanol to provide hydrogen and produces acetone as a byproduct $^{23}$

Influence of Methanol/Water Ratio. Figure 2 shows the influence of the methanol/water ratio on the lignin monomer yield, the delignification degree, and the hydrogen yield at the optimized temperature of $230{ }^{\circ} \mathrm{C}$. When pure methanol was used as the solvent the delignification degree was $88 \%$. By increasing the water content, the delignification degree increased to an optimum value of $99 \%$ at an equimolar methanol/water ratio. Notably, the delignification degree in pure water was lower $(86 \%)$. However, high water concentration also results in the removal of hemicellulose and partial removal of cellulose (Figure S1). Cellulose retention was $41 \mathrm{wt} \%$, and hemicellulose retention was lower than 1 wt $\%$ in an experiment with a molar methanol/ water ratio of $1 / 2$ at $230{ }^{\circ} \mathrm{C}$. The solvent composition also affects the lignin monomer yield and product distribution. In pure methanol, a monomer yield of only $19 \%$ was obtained. The yield significantly increased to $37 \%$ when the molar methanol/water ratio was 2 . The addition of water to methanol (methanol-water volume ratio $1 / 3$ ) decreased the monomer yield in the birch wood lignin conversion using a $\mathrm{Ni} / \mathrm{C}$ catalyst in an earlier report. ${ }^{26} \mathrm{We}$ found that the optimum yield of $49 \%$ was obtained when the methanol/water ratio was $1 / 2$. The increased lignin monomer yield is attributed to the higher hydrogen yield obtained when the methanol/water ratio is lower (Figure 2b). Hydrogen can effectively hydrogenate the reactive functional groups in dissolved lignin fragments through catalytic reduction, e.g., the hydrogenation of unsaturated side chains and the hydrodeoxygenation of ketones and aldehydes. ${ }^{7}$ This reduction essentially prevents undesirable lignin repolymerization and results in a high yield of stable phenolic monomers. The highest monomer yield (49 wt \%) was obtained for a molar methanol/water ratio of $1 / 2$ at $230{ }^{\circ} \mathrm{C}$. Compared to lower temperatures, these reaction conditions resulted in relatively lower cellulose/hemicellulose retention and lower mass balance closure (73 wt \%), presumably due to secondary reactions involving solubilized carbohydrates (Table S3). In pure water, the lignin monomer yield dropped to $6 \%$, which is most likely due to a lack of hydrogen. The lignin monomer yield in pure water is lower than in an organic solvent-water mixture and strongly influenced by the use of different catalysts $(\mathrm{Ru} / \mathrm{C}, \mathrm{Pd} / \mathrm{C}$, $\mathrm{Rh} / \mathrm{C}$, and $\mathrm{Pt} / \mathrm{C}$ ) even in the presence of external hydrogen. ${ }^{37}$ Gas product analysis (Figure $2 \mathrm{~b}$ ) also shows that hydrogen cannot be effectively obtained by reforming of carbohydrates released from the biomass matrix under these conditions in pure water. Furthermore, a control experiment was performed under identical conditions in the presence of Pt-base catalyst but without birch wood. An amount of $14.7 \mathrm{mmol}$ of hydrogen is produced from the methanol-water mixture (molar ratio 1/ 2 ), which corresponds to $0.8 \mathrm{~mol} \%$ of the starting methanol (Table S4). This further confirms that hydrogen is mainly generated from Pt-catalyzed methanol reforming. An earlier study found that formic acid, which acts as the hydrogen donor, is released during the pulping process in birch wood lignin depolymerization in an ethanol/water mixture. It was also established that ethanol did not act as the hydrogen donor under the reaction conditions. ${ }^{38}$ Regarding the products obtained, unsaturated 4-propenyl-syringol is the main product in the absence of water. Due to the increased production of hydrogen, the selectivity shifts from 4-propenyl-syringol to 4propyl-syringol when the water content is increased. The addition of water to methanol not only changes the lignin yield and monomer selectivity but also decreases the operating cost of whole process. Thus, we conclude that the production of hydrogen by reforming of methanol has a positive effect on the reductive fractionation of lignocellulosic biomass into phenolic monomers.

Influence of the Catalyst. We next investigated the role of the catalyst. Extraction of the lignin fragments involves the cleavage of lignin-carbohydrate interlinkages, which are typically comprised of phenyl glycoside, $\gamma$-ester, and benzyl ether bonds. ${ }^{39}$ Given that the substrate to be converted during extraction is a large polymer, accessibility of the reactive bonds is limited for heterogeneous catalysts. Nevertheless, it has been 
reported that a heterogeneous metal catalyst can promote the cleavage of ether bonds under mild reaction conditions. ${ }^{40}$

Table 2 shows that the delignification degree without catalyst is comparable to the case where $\mathrm{Pt} / \gamma-\mathrm{Al}_{2} \mathrm{O}_{3}$ is used as

Table 2. Results of Birch Wood Upgrading under Various Conditions $^{a}$

$\begin{array}{cccccc}\text { entry } & \text { catalyst } & \text { gas } & \begin{array}{c}\text { delignification } \\ (\%)\end{array} & \begin{array}{c}\text { monomer } \\ \text { yield }(\%)\end{array} & \begin{array}{c}\mathrm{H}_{2} \text { yield } \\ (\mathrm{mmol})\end{array} \\ 1^{b} & \mathrm{Pt} / \gamma-\mathrm{Al}_{2} \mathrm{O}_{3} & \mathrm{~N}_{2} & 94 & 49 & 3.1 \\ 2 & \mathrm{Pt} / \gamma-\mathrm{Al}_{2} \mathrm{O}_{3} & \mathrm{H}_{2} & 102 & 43 & \\ 3 & & \mathrm{~N}_{2} & 95 & 1 & 0 \\ 4^{c} & \mathrm{Pt} / \gamma-\mathrm{Al}_{2} \mathrm{O}_{3} & \mathrm{~N}_{2} & 101 & 7 & 0.4\end{array}$

${ }^{a}$ Experimental conditions: $2.0 \mathrm{~g}$ of pretreated birch wood (Klason lignin content $20.1 \mathrm{wt} \%), 40 \mathrm{~mL}$ of methanol/water $(1 / 2 \mathrm{~mol} / \mathrm{mol})$, $230{ }^{\circ} \mathrm{C}, 3$ h. ${ }^{b} 500 \mathrm{mg}$ of $1 \mathrm{wt} \% \mathrm{Pt} / \gamma-\mathrm{Al}_{2} \mathrm{O}_{3} \cdot{ }^{c} 250 \mathrm{mg}$ of $1 \mathrm{wt} \% \mathrm{Pt} / \gamma-$ $\mathrm{Al}_{2} \mathrm{O}_{3}$.

the catalyst. The high delignification degree is therefore mainly due to solvolysis of the indicated chemical bonds, which benefits from the relatively high reaction temperature of 230 ${ }^{\circ} \mathrm{C}$. The slightly higher than expected delignification degree is due to the formation of a small amount of condensation products of carbohydrate-derived compounds (humins) and other condensation products between carbohydrate-derived compounds and lignin fragments. ${ }^{41}$

After release into the solution, the dissolved lignin fragments are depolymerized to aromatic monomers through cleavage of the dominant $\beta-\mathrm{O}-4$ bonds. The chemical structure of the main components in the lignin oil was investigated by $2 \mathrm{D}$ HSQC NMR spectroscopy (Figure 3). A lignin oil obtained by delignification in methanol under mild conditions without a catalyst (Supporting Information section 6.1) exhibits characteristic signals of $\beta-\mathrm{O}-4, \alpha-\mathrm{O}-4 / \beta-5$, and $\beta-\beta$ bonds in the NMR spectra shown in Figure 3a. The characteristic cross-signals of the guaiacol $(G)$ and syringol $(S)$ units of the lignin oil can be clearly seen in the spectra (Figure $3 e-h$ ). Notably, we found the cross-signals of coniferyl/sinapyl alcohol (structure I) and oxidized syringyl unit (structure $S^{\prime}$ ) in the lignin oil obtained under mild delignification conditions (Figure $3 \mathrm{e}$ ). The use of $\mathrm{Pt} / \gamma-\mathrm{Al}_{2} \mathrm{O}_{3}$ as the catalyst in an inert

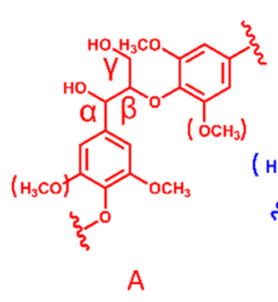

(a)

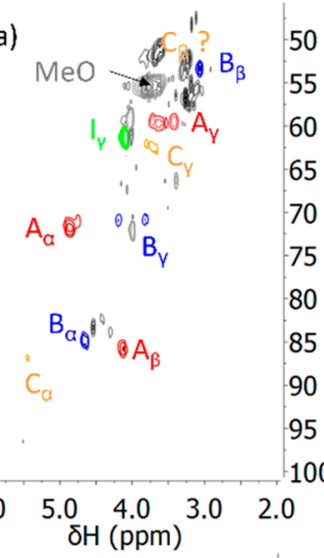

(e) $\quad 96$

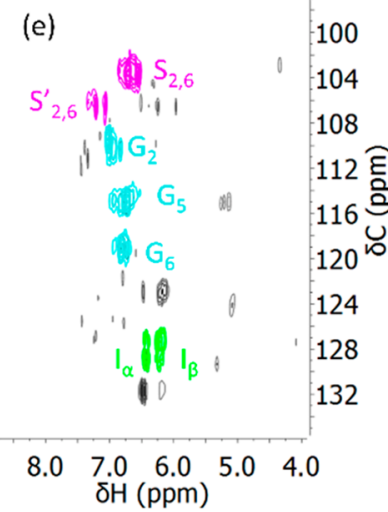

(b)<smiles>CCCCCCCCCCCCCCCCCC</smiles>
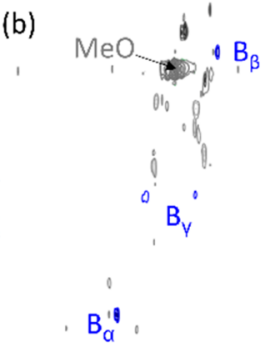

$B_{a}^{\prime \prime}$

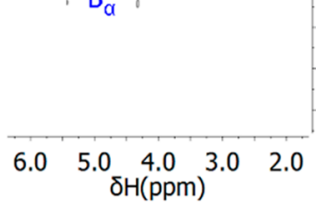

(f)

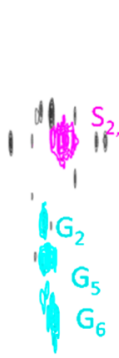

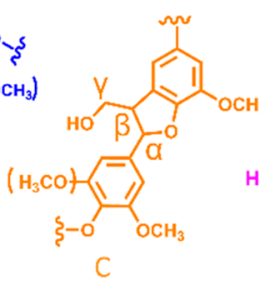

$\mathrm{S}$

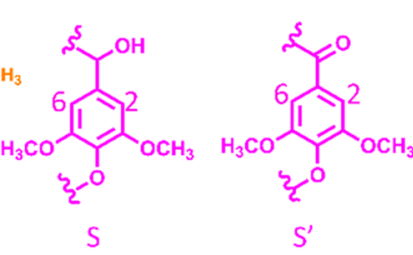

$-50$

60

65

$70 \widehat{\hat{\mathrm{o}}}$

(c) MeO

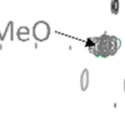

$\begin{array}{ll}0 & B \\ 0 & 0 \\ B_{Y} & 0\end{array}$

$\mathrm{B}_{\mathrm{c}}{ }^{\prime}$

100

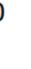

$\begin{array}{lllll}6.0 & 5.0 & 4.0 & 3.0 & 2.0\end{array}$

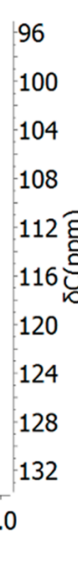<smiles>CCOc1ccc(C(O)CC)cc1OC</smiles><smiles>COc1cc(/C=C/CO)cc(OC)c1OP</smiles>

(d)

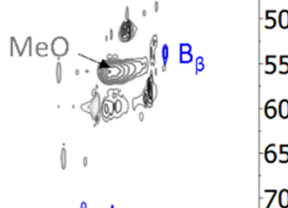

$-55$

60

70

75 문

80

85

90

95

$-100$

100

$\begin{array}{llll}6.0 & 5.0 \\ \delta \mathrm{H}(\mathrm{nom}) & 4.0 & 2.0\end{array}$

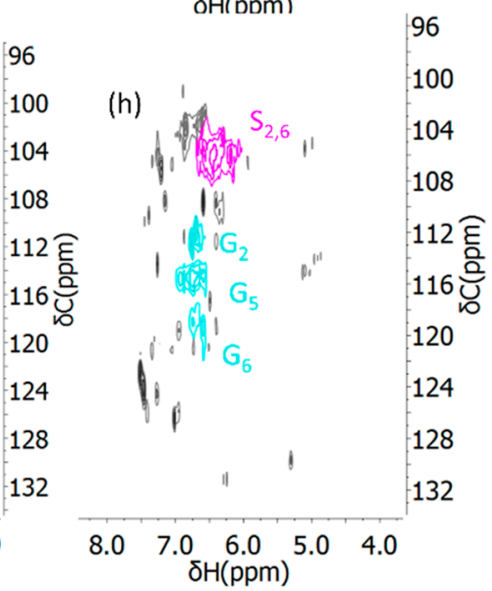

Figure 3. Aliphatic side-chain (top, a-d) and aromatic (bottom, e-h) regions of ${ }^{1} \mathrm{H}-{ }^{13} \mathrm{C}$ HSQC NMR spectra of the lignin oils obtained by treatment of sawdust of birch wood (a, e) under mild organosolv conditions (methanol, 30 bar $\mathrm{N}_{2}, 170{ }^{\circ} \mathrm{C}, 2 \mathrm{~h}$ ) and in the presence of (b, f) $30 \mathrm{bar}$ $\mathrm{N}_{2}$ and $\mathrm{Pt} / \gamma-\mathrm{Al}_{2} \mathrm{O}_{3},(\mathrm{c}, \mathrm{g}) 30$ bar $\mathrm{H}_{2}$ and $\mathrm{Pt} / \gamma-\mathrm{Al}_{2} \mathrm{O}_{3}$, and $(\mathrm{d}, \mathrm{h}) 30$ bar $\mathrm{N}_{2}$ without catalyst. 
nitrogen atmosphere results in the removal of all of these $\beta-\mathrm{O}$ 4 and $\alpha-\mathrm{O}-4$ bonds (Figure $3 \mathrm{~b}$ ) and also the unsaturated coniferyl/sinapyl alcohol and oxidized syringyl units (Figure 3f). The use of external hydrogen (Figure $3 \mathrm{c}$ and $3 \mathrm{~g}$ ) shows similar results to those with nitrogen. It is interesting to note that the $\beta-\mathrm{O}-4$ bonds were also not observed without the $\mathrm{Pt}$ / $\gamma-\mathrm{Al}_{2} \mathrm{O}_{3}$ catalyst (Figure 3d). These findings indicate that cleavage of $\beta-\mathrm{O}-4$ bonds does not require a catalyst and mainly occurs via thermal solvolysis. Nevertheless, the lignin monomer yield in this approach is very low due to the condensation of reactive lignin groups. The disappearance of coniferyl/sinapyl alcohol and unsaturated syringyl units in Figure $3 \mathrm{~d}$ and $3 \mathrm{~h}$ might be caused by the condensation of these reactive unsaturated groups. ${ }^{42,43}$ The delignification in alcohol/water mixtures as employed here draws similarities with organosolv processes in which lignin is released from the native biomass structure due to solvolysis of lignincarbohydrate bonds and also cleavage of $\beta-\mathrm{O}-4$ bonds. The mechanism of $\beta-\mathrm{O}-4$ bond cleavage in the organosolv pulping process has been studied in some detail. ${ }^{43}$ The formation of unstable lignin intermediates, such as benzylic cations and unsaturated monomers, will result in condensation into less reactive lignin oligomers. ${ }^{44,45}$

The lignin monomer yields are shown in Table 2. Using Pt/ $\gamma-\mathrm{Al}_{2} \mathrm{O}_{3}$ as the catalyst in a nitrogen atmosphere, up to $49 \%$ of lignin monomers can be obtained. This shows that condensation is suppressed by hydrogenation of the reactive groups formed upon solvolysis of the $\beta-\mathrm{O}-4$ bonds. Analysis of the gaseous products showed that $3.1 \mathrm{mmol}$ of hydrogen was formed. When external hydrogen gas was used, a slightly lower lignin monomer yield of $43 \%$ was obtained (entry 2 ). A similar phenomenon was observed in the transfer hydogenolysis of lignin to monomers over $\mathrm{Ni} / \mathrm{C}$ catalyst. ${ }^{26}$ A possible explanation is a more intense gas/liquid contact when hydrogen is generated close to the sites where also hydrodeoxygenation/hydrogenation of unstable lignin monomer takes place. ${ }^{26}$ Without a catalyst (entry 3 ) the lignin monomer yield was very low (1\%), showing that the lignin monomers obtained by $\beta-\mathrm{O}-4$ cleavage rapidly condense. When we decrease in entry 4 the $\mathrm{Pt} / \gamma-\mathrm{Al}_{2} \mathrm{O}_{3}$ loading to one-half of the amount used in entry 2 we find a much lower hydrogen yield of $0.4 \mathrm{mmol}$ and consequently also a decreased lignin monomer yield (7\%).

The catalytic results in Table 2 and the ${ }^{1} \mathrm{H}-{ }^{13} \mathrm{C}$ HSQC NMR spectra in Figure 3 point to the critical role of the $\mathrm{Pt} / \gamma$ $\mathrm{Al}_{2} \mathrm{O}_{3}$ catalyst for obtaining a high monomer yield in the current process. To further support this role, gel permeation chromatography (GPC) was applied to determine the molecular weight distribution of obtained lignin oils (Figure 4). Without a catalyst the peak of monomers is not observed and the lignin oil is mainly composed of dimers and oligomers. This is in line with the low monomer yield (entry 3, Table 2). In the presence of $\mathrm{Pt} / \gamma-\mathrm{Al}_{2} \mathrm{O}_{3}$ and hydrogen, a monomer feature appears in the chromatograms, indicative that the dimers and oligomers are converted into monomers. Using $\mathrm{Pt} /$ $\gamma-\mathrm{Al}_{2} \mathrm{O}_{3}$ in a nitrogen atmosphere, the molecular weight distribution of the lignin oil is very similar to the one obtained in an hydrogen atmosphere. This indicates that hydrogen generated by methanol reforming has a comparable effect to applying an external hydrogen pressure with respect to reductive depolymerization of lignin fragments.

We also evaluated whether the Pt-based catalyst can be replaced by other supported metal catalysts (Table 3 ). These

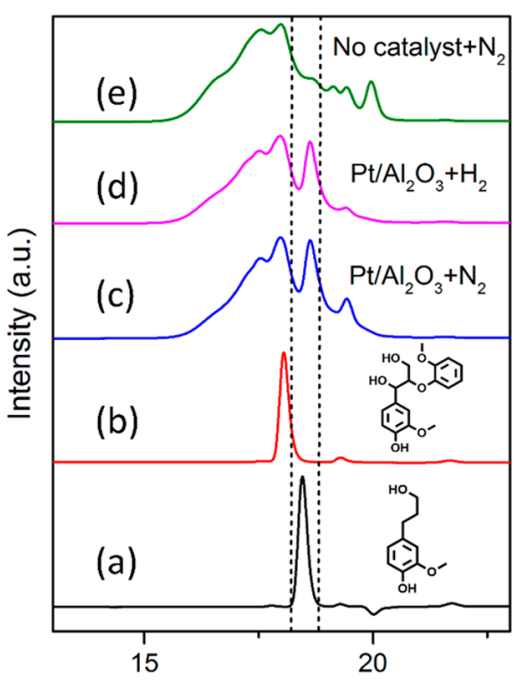

Retention time (min)

Figure 4. Gel permeation chromatograms of model compounds (a) 4$n$-propanol-guaiacol, (b) guaiacylglycerol- $\beta$-guaiacyl ether, and of lignin oil obtained from birch wood in the presence of (c) 30 bar $\mathrm{N}_{2}$ and $\mathrm{Pt} / \gamma-\mathrm{Al}_{2} \mathrm{O}_{3}$, (d) 30 bar $\mathrm{H}_{2}$ and $\mathrm{Pt} / \gamma-\mathrm{Al}_{2} \mathrm{O}_{3}$, and (e) 30 bar $\mathrm{N}_{2}$ without catalyst.

Table 3. Comparison of the Delignification Degree, Monomer, and Hydrogen Yield during Catalytic Birch Wood Upgrading in Methanol/Water ${ }^{a}$

\begin{tabular}{clccc} 
entry & \multicolumn{1}{c}{ metal catalyst } & $\begin{array}{c}\text { delignification } \\
\text { degree }(\%)\end{array}$ & $\begin{array}{c}\text { monomer } \\
\text { yield }(\%)\end{array}$ & $\begin{array}{c}\mathrm{H}_{2} \text { yield } \\
(\mathrm{mmol})\end{array}$ \\
$1^{b}$ & $\mathrm{Pt} / \mathrm{C}$ & 103 & 45 & 2.4 \\
$2^{c}$ & $\mathrm{Pd} / \mathrm{C}$ & 109 & 22 & 0.1 \\
$3^{d}$ & $\mathrm{Cu} / \mathrm{ZnO} / \mathrm{Al}_{2} \mathrm{O}_{3}$ & 104 & 2 & 0.9 \\
$4^{e}$ & $\mathrm{Cu} / \mathrm{CeO}_{2}$ & 104 & 5 & 0 \\
$5^{f}$ & $\mathrm{Mo}_{2} \mathrm{C} / \mathrm{AC}$ & 103 & 5 & 0.4
\end{tabular}

${ }^{a}$ Experimental conditions: $2.0 \mathrm{~g}$ of birch sawdust, $40 \mathrm{~mL}$ of methanol/ water $(1 / 2 \mathrm{~mol} / \mathrm{mol}), 230{ }^{\circ} \mathrm{C}, 3 \mathrm{~h} .{ }^{b} 5$ wt $\% \mathrm{Pt} / \mathrm{C}, 100 \mathrm{mg} .{ }^{{ }^{c}} 5$ wt $\%$ $\mathrm{Pd} / \mathrm{C}, 100 \mathrm{mg} .{ }^{d} \mathrm{Cu}, \mathrm{ZnO}$, and $\mathrm{Al}_{2} \mathrm{O}_{3}$ ratio is $4 / 4 / 2$, catalyst loading is $100 \mathrm{mg} .{ }^{e} 100 \mathrm{mg}$ of $5 \mathrm{wt} \% \mathrm{Cu} / \mathrm{CeO} 2 .{ }^{f} 100 \mathrm{mg}$ of $18 \mathrm{wt} \% \mathrm{Mo}_{2} \mathrm{C} /$ AC.

catalysts were selected because of their high activity in hydrogenation or methanol reforming. The delignification degree was not influenced by the type of catalyst, which is in line with the results in Table 2, emphasizing that delignification is a solvolysis process. In the use of $\mathrm{Pt} / \gamma-\mathrm{Al}_{2} \mathrm{O}_{3}$, the formation of boehmite was confirmed by XRD analysis of spent $\mathrm{Pt} / \gamma$ $\mathrm{Al}_{2} \mathrm{O}_{3}$, which indicates the instability of $\mathrm{Al}_{2} \mathrm{O}_{3}$ support in methanol reforming conditions (Figure $\mathrm{S} 4$ ). Carbon as a support is argued to be more stable than $\gamma-\mathrm{Al}_{2} \mathrm{O}_{3}$ in an earlier study. ${ }^{32}$ Therefore, we replaced $\mathrm{Pt} / \gamma-\mathrm{Al}_{2} \mathrm{O}_{3}$ with $\mathrm{Pt} / \mathrm{C}$ and achieved a nearly similar lignin monomer yield at complete delignification (entry 1). $\mathrm{Pd} / \mathrm{C}$ has been successfully used in the hydrogenolysis of ether bonds of lignin. ${ }^{46}$ Entry 2 shows that $\mathrm{Pd} / \mathrm{C}$ can yield up to $22 \%$ lignin monomers. The lower yield is likely due to a lower activity of the catalyst in methanol reforming, as evident from the lower hydrogen yield. Entry 3 shows that $\mathrm{Cu} / \mathrm{ZnO} / \mathrm{Al}_{2} \mathrm{O}_{3}$, which is a known catalyst for methanol synthesis, can form hydrogen from the solvent mixture in line with earlier reports. ${ }^{2}$ However, the lignin monomer yield for this catalyst was very low because of the relatively low hydrogenation activity of $\mathrm{Cu}$. The result was 
similar for $\mathrm{Cu} / \mathrm{CeO}_{2}$ (entry 4). On the basis of an earlier report that $\mathrm{Mo}_{2} \mathrm{C} / \mathrm{C}$ is a suitable catalyst for $\mathrm{Kraft}$ depolymerization and methanol reforming, ${ }^{4,48}$ we also evaluated this catalyst prepared by carbothermal reduction (Supporting Information section 1.2). The relatively low lignin monomer yield is most likely due to the relatively low reaction temperature compared to the literature in which harsh conditions $\left(300-400{ }^{\circ} \mathrm{C}\right)$ were used to upgrade technical lignin.

Model Compound Study. The above results show the importance of the methanol/water solvent and a metal catalyst to our process. Lignin is extracted from the lignocellulosic matrix by solvolysis and depolymerized into unstable monomers in methanol/water through solvolysis. The use of $\mathrm{Pt} / \gamma-\mathrm{Al}_{2} \mathrm{O}_{3}$ promotes methanol reforming reactions which provide hydrogen and also prevent undesired lignin fragment repolymerization, thereby increasing the monomer yield. To understand these aspects in more detail, we also performed a similar set of experiments by using a representative lignin dimer model compound, namely, guaiacylglycerol- $\beta$-guaiacyl ether as the substrate. The main products are guaiacol, propylguaiacol, ethylguaiacol, and methylguaiacol, and their yields are shown in Figure 5. In the use of $\mathrm{Pt} / \gamma-\mathrm{Al}_{2} \mathrm{O}_{3}$ catalyst
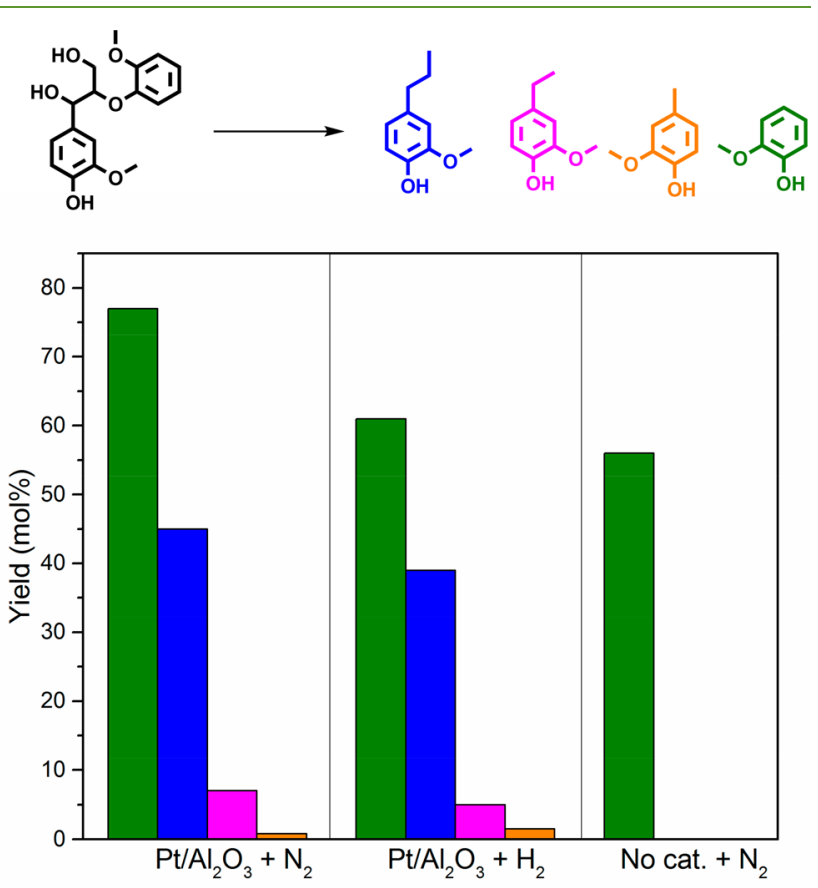

Figure 5. Catalytic results of model compound conversion under different conditions.

under 30 bar of nitrogen, the $\beta-\mathrm{O}-4$ bonds were efficiently cleaved and up to $77 \%$ of guaiacol was obtained (Figure 5). A small amount of methylguaiacol was detected due to the methylation of obtained guaiacol with methanol in the reaction. The formation of propyl- and ethylguaiacol can be taken as an indication that the mechanism of $\beta-\mathrm{O}-4$ bond cleavage involves the acidolysis or the solvolysis. The acidolysis of the $\beta-\mathrm{O}-4$ bond involves two pathways: one is the Hibbert ketone pathway that leads to the phenolic C3-ketones; the other one involves decarbonylation resulting in a C2aldehyde. ${ }^{49} \mathrm{Pt} / \gamma-\mathrm{Al}_{2} \mathrm{O}_{3}$ promotes the hydrogenation of the unsaturated $\mathrm{C} 3$-ketone and $\mathrm{C} 2$-aldehyde to propyl- and ethyl- guaiacol, respectively. The high yield of propyl guaiacol in the model experiment shows that the Hibbert ketone (C3) pathway might be the main route for $\beta-\mathrm{O}-4$ bond cleavage. Another possible mechanism is that the coniferyl alcohols are formed as the main intermediates in the solvolysis process. ${ }^{25,42}$ These intermediates are hydrogenated to propanol/propyl guaiacol in the presence of Pt-based catalyst. The ethylsubstituted monomer is formed due to cleavage of the $\mathrm{CH}_{2} \mathrm{OH}$ group from the propanol guaiacol. ${ }^{50}$ From the observation that the propyl/ethylguaiacol and guaiacol ratio was lower than one, we infer that a small amount of monomers was polymerized to high molecular weight products, even in the presence of the catalyst. The use of external hydrogen leads to similar results, suggesting that some polymerization is inevitable. Without catalyst in a nitrogen atmosphere cleavage of the $\beta-\mathrm{O}-4$ bond still occurs, resulting in a considerable yield of guaiacol as the only product. The disappearance of propyland ethylguaiacol is likely due to the polymerization involving the unsaturated monomers.'

Proposed Mechanism. In the reductive lignin depolymerization the roles of each step, namely, lignin extraction, depolymerization, and monomer stabilization, have already been well investigated for the case that external hydrogen gas is present. $^{14}$ Our results clearly show that effective hydrogen generation for monomer stabilization is also important to obtain a high lignin monomer yield from birch sawdust in our approach. Lignin fragments are extracted from the lignocellulosic biomass matrix through solvolysis, and these fragments are further converted into phenolic monomers. Acidolysis/ solvolysis underlies the removal of lignin fragments from the biomass matrix as well as its depolymerization, primarily resulting in unsaturated monomers. Without catalyst these reactive intermediates condense into high molecular weight products, explaining the low monomer yield in the absence of a hydrogenation function. The use of a Pt-based catalyst is crucial to obtain a high lignin monomer yield. A methanol/ water solvent can be used to provide hydrogen through methanol reforming. The Pt-based catalyst also promotes hydrogenation reactions of the unsaturated side chains to stabilize the reactive intermediates, contributing to a high lignin monomer yield.

\section{CONCLUSIONS}

We developed an alternative strategy for the reductive depolymerization of in planta lignin into phenolic monomers using a Pt-based catalyst with methanol/water as a safe and effective hydrogen source. In this study, the influence of temperature and methanol/water ratio is investigated. Nearly complete delignification (94\%) and a high yield of aromatic monomers (49\%) can be obtained from birch sawdust under optimized conditions $\left(230^{\circ} \mathrm{C}, 30\right.$ bar $\mathrm{N}_{2}, 3 \mathrm{~h}$, methanol/water molar ratio $1 / 2$ ). The product selectivity can be tuned between 4-propenyl-syringol and 4-propyl-syringol by changing the hydrogenation formation rate through methanol reforming. Model compound experiments and HSQC NMR analysis of lignin oil reveal the solvolytic cleavage of the dominant $\beta-\mathrm{O}-4$ bond and the importance of monomer stabilization in the present process. Lignin is extracted from the lignocellulosic matrix and depolymerized to an unstable intermediate through $\beta-\mathrm{O}-4$ bond cleavage. The Pt-based catalyst essentially catalyzes the methanol reforming for hydrogen generation and also the reductive stabilization of unstable lignin intermediates. The latter aspect is important to prevent 
unfavorable lignin condensation. Overall, this approach provides an effective strategy for the lignin catalytic conversion without using external hydrogen.

\section{ASSOCIATED CONTENT}

\section{S Supporting Information}

The Supporting Information is available free of charge on the ACS Publications website at DOI: 10.1021/acssuschemeng.9b01497.

Details of $\mathrm{Cu} / \mathrm{ZnO} / \mathrm{Al}_{2} \mathrm{O}_{3}, \mathrm{Cu} / \mathrm{CeO}_{2}, \mathrm{Mo} 2 \mathrm{C} / \mathrm{AC}$ catalysts preparation; carbohydrate retention in solid residue; birch wood mass balance; water phase products; gaseous products in the methanol reforming; XRD of spent $\mathrm{Pt} / \gamma-\mathrm{Al}_{2} \mathrm{O}_{3}$ (PDF)

\section{AUTHOR INFORMATION}

\section{Corresponding Authors}

*Tel: +31 40247 5178; E-mail: x.huang@tue.nl.

*Tel: +31 40247 5178; E-mail: e.j.m.hensen@tue.nl.

ORCID $\odot$

Emiel J. M. Hensen: 0000-0002-9754-2417

Notes

The authors declare no competing financial interest.

\section{ACKNOWLEDGMENTS}

X.O. thanks the China Scholarship Council for financial support.

\section{REFERENCES}

(1) Upton, B. M.; Kasko, A. M. Strategies for the conversion of lignin to high-value polymeric materials: review and perspective. Chem. Rev. 2016, 116 (4), 2275-2306.

(2) Song, S.; Zhang, J.; Gozaydın, G.; Yan, N. Production of terephthalic acid from corn stover lignin. Angew. Chem. 2019, 131 (15), 4988-4991.

(3) Yuan, T. Q.; Sun, S. N.; Xu, F.; Sun, R. C. Characterization of lignin structures and lignin-carbohydrate complex (LCC) linkages by quantitative 13C and 2D HSQC NMR spectroscopy. J. Agric. Food Chem. 2011, 59 (19), 10604-10614.

(4) Zhou, C. H.; Xia, X.; Lin, C. X.; Tong, D. S.; Beltramini, J. Catalytic conversion of lignocellulosic biomass to fine chemicals and fuels. Chem. Soc. Rev. 2011, 40 (11), 5588-5617.

(5) Ragauskas, A. J.; Beckham, G. T.; Biddy, M. J.; Chandra, R.; Chen, F.; Davis, M. F.; Davison, B. H.; Dixon, R. A.; Gilna, P.; Keller, M.; Langan, P.; Naskar, A. K.; Saddler, J. N.; Tschaplinski, T. J.; Tuskan, G. A.; Wyman, C. E. Lignin valorization: improving lignin processing in the biorefinery. Science 2014, 344 (6185), 12468431246843.

(6) Luterbacher, J. S.; Azarpira, A.; Motagamwala, A. H.; Lu, F.; Ralph, J.; Dumesic, J. A. Lignin monomer production integrated into the $\gamma$-valerolactone sugar platform. Energy Environ. Sci. 2015, 8 (9), 2657-2663.

(7) Rinaldi, R.; Jastrzebski, R.; Clough, M. T.; Ralph, J.; Kennema, M.; Bruijnincx, P. C. A.; Weckhuysen, B. M. Paving the way for lignin valorisation: recent advances in bioengineering, biorefining and catalysis. Angew. Chem., Int. Ed. 2016, 55 (29), 8164-8215.

(8) Parsell, T. H.; Owen, B. C.; Klein, I.; Jarrell, T. M.; Marcum, C. L.; Haupert, L. J.; Amundson, L. M.; Kenttämaa, H. I.; Ribeiro, F.; Miller, J. T.; Abu-Omar, M. M. Cleavage and hydrodeoxygenation (HDO) of $\mathrm{C}-\mathrm{O}$ bonds relevant to lignin conversion using $\mathrm{Pd} / \mathrm{Zn}$ synergistic catalysis. Chem. Sci. 2013, 4 (2), 806-813.

(9) Deuss, P. J.; Scott, M.; Tran, F.; Westwood, N. J.; De Vries, J. G.; Barta, K. Aromatic monomers by in situ conversion of reactive intermediates in the acid-catalyzed depolymerization of lignin. J. Am. Chem. Soc. 2015, 137 (23), 7456-7467.
(10) Rahimi, A.; Ulbrich, A.; Coon, J. J.; Stahl, S. S. Formic-acidinduced depolymerization of oxidizedlignin to aromatics. Nature 2014, 515 (7526), 249-252.

(11) Huang, X.; Morales Gonzalez, O. M.; Zhu, J.; Koranyi, T. I.; Boot, M. D.; Hensen, E. J. M. Reductive fractionation of woody biomass into lignin monomers and cellulose by tandem metal triflate and Pd/C catalysis. Green Chem. 2017, 19 (1), 175-187.

(12) Ouyang, X.; Huang, X.; Hendriks, B. M. S.; Boot, D.; Hensen, E. J. M. Coupling organosolv fractionation and reductive depolymerization of woody biomass in a two-step catalytic process. Green Chem. 2018, 20 (10), 2308-2319.

(13) Renders, T.; Van den Bosch, S.; Koelewijn, S.-F.; Schutyser, W.; Sels, B. F. Lignin-first biomass fractionation: the advent of active stabilisation strategies. Energy Environ. Sci. 2017, 10 (7), 1551-1557.

(14) Van den Bosch, S.; Renders, T.; Kennis, S.; Koelewijn, S.-F.; Van den Bossche, G.; Vangeel, T.; Deneyer, A.; Depuydt, D.; Courtin, C. M.; Thevelein, J. M.; Schutyser, W.; Sels, B. F. Integrating lignin valorization and bio-ethanol production: on the role of $\mathrm{Ni}-\mathrm{Al}_{2} \mathrm{O}_{3}$ catalyst pellets during lignin-first fractionation. Green Chem. 2017, 19 (14), 3313-3326.

(15) Zhang, K.; Pei, Z.; Wang, D. Organic solvent pretreatment of lignocellulosic biomass for biofuels and biochemicals: A review. Bioresour. Technol. 2016, 199, 21-33.

(16) Shuai, L.; Luterbacher, J. Organic solvent effects in biomass conversionreactions. ChemSusChem 2016, 9 (2), 133-155.

(17) Luo, H.; Abu-Omar, M. M. Lignin extraction and catalytic upgrading from genetically modified poplar. Green Chem. 2018, 20 (3), 745-753.

(18) Van den Bosch, S.; Schutyser, W.; Vanholme, R.; Driessen, T.; Koelewijn, S.-F.; Renders, T.; De Meester, B.; Huijgen, W. J. J.; Dehaen, W.; Courtin, C. M.; Lagrain, B.; Boerjan, W.; Sels, B. F. Reductive lignocellulose fractionation into soluble lignin-derived phenolic monomers and dimers and processable carbohydrate pulps. Energy Environ. Sci. 2015, 8 (6), 1748-1763.

(19) Anderson, E. M.; Stone, M. L.; Katahira, R.; Reed, M.; Beckham, G. T.; Román-Leshkov, Y. Flowthrough reductive catalytic fractionation of biomass. Joule 2017, 1 (3), 613-622.

(20) Anderson, E. M.; Stone, M. L.; Hülsey, M. J.; Beckham, G. T.; Román-Leshkov, Y. Kinetic Studies of lignin solvolysis and reduction by reductive catalytic fractionation decoupled in flow-through Reactors. ACS Sustainable Chem. Eng. 2018, 6 (6), 7951-7959.

(21) Agrell, J.; Lindstöm, B.; Pettersson, L. J.; Järås, S. G. Catalytic hydrogen generation from methanol. Catalysis; Royal Society of Chemistry: Cambridge, 2002; pp 67-132.

(22) Cortright, R. D.; Davda, R. R.; Dumesic, J. A. Hydrogen from catalytic reforming of biomass-derived hydrocarbons in liquid water. Nature 2002, 418 (6901), 964-967.

(23) Ferrini, P.; Rinaldi, R. Catalytic biorefining of plant biomass to non-pyrolytic lignin bio-oil and carbohydrates through hydrogen transfer reactions. Angew. Chem., Int. Ed. 2014, 53 (33), 8634-8639.

(24) Rautiainen, S.; Di Francesco, D.; Katea, S. N.; Westin, G.; Tungasmita, D. N.; Samec, J. S. M. Ligninvalorizationby cobaltcatalyzedfractionationoflignocelluloseto yield monophenoliccompounds. ChemSusChem 2019, 12 (2), 404-408.

(25) Kumaniaev, I.; Subbotina, E.; Sävmarker, S. J.; Larhed, M.; Galkin, M. V.; Samec, J. S. M. Lignin depolymerization to monophenolic compounds in a flow-through system. Green Chem. 2017, 19 (24), 5767-5771.

(26) Song, Q.; Wang, F.; Cai, J.; Wang, Y.; Zhang, J.; Yu, W.; Xu, J. Lignin depolymerization (LDP) in alcohol over nickel- based catalysts via a fragmentation-hydrogenolysis process. Energy Environ. Sci. 2013, 6 (3), 994-1007.

(27) Zakzeski, J.; Jongerius, A. L.; Bruijnincx, P. C. A.; Weckhuysen, B. M. Catalytic lignin valorization process for the production of aromatic chemicals and hydrogen. ChemSusChem 2012, 5 (8), 16021609.

(28) Renders, T.; Van den Bosch, S.; Vangeel, T.; Ennaert, T.; Koelewijn, S.-F.; Van den Bossche, G.; Courtin, C. M.; Schutyser, W.; Sels, B. F. Synergetic effects of alcohol/water mixing on the catalytic 
reductive fractionation of poplar wood. ACS Sustainable Chem. Eng. 2016, 4 (12), 6894-6904.

(29) Sluiter, A.; Hames, B.; Ruiz, R.; Scarlata, C.; Sluiter, J.; Templeton, D.; Crocker, D. Determination of Structural Carbohydrates and Lignin in Biomass; National Renewable Energy Laboratory, 2012.

(30) Davda, R. R.; Dumesic, J. A. Renewable hydrogen by aqueousphase reforming of glucose. Chem. Commun. 2004, o (1), 36-37.

(31) Alonso, D. M.; Bond, J. Q.; Dumesic, J. A. Catalytic conversion of biomass to biofuels. Green Chem. 2010, 12 (9), 1493-1513.

(32) Jongerius, A. L.; Copeland, J. R.; Foo, G. S.; Hofmann, J. P.; Bruijnincx, P. C. A.; Sievers, C.; Weckhuysen, B. M. Stability of Pt $/ \gamma$ $\mathrm{Al}_{2} \mathrm{O}_{3}$ catalysts in lignin and lignin model compound solutions under liquid phase reforming reactionconditions. ACS Catal. 2013, 3 (3), 464-473.

(33) Sun, Z.; Fridrich, B.; de Santi, A.; Elangovan, S.; Barta, K. Bright side of lignin depolymerization: toward new platform chemicals. Chem. Rev. 2018, 118 (2), 614-678.

(34) Palo, D. R.; Dagle, R. A.; Holladay, J. D. Methanol steam reforming for hydrogen production. Chem. Rev. 2007, 107 (10), 3992-4021.

(35) Hu, X.; Lievens, C.; Li, C. Z. Acid-catalyzed conversion of xylose in methanol-rich medium as part of biorefinery. ChemSusChem 2012, 5 (8), 1427-1434.

(36) Galkin, M. V.; Smit, A. T.; Subbotina, E.; Artemenko, K. A.; Bergquist, J.; Huijgen, W. J. J.; Samec, J. S. M. Hydrogen-free catalytic fractionation of woody biomass. ChemSusChem 2016, 9 (23), 32803287.

(37) Yan, N.; Zhao, C.; Dyson, P. J.; Wang, C.; Liu, L. T.; Kou, Y. Selective degradation of wood lignin over noble-metal catalysts in a two-step process. ChemSusChem 2008, 1 (7), 626-629.

(38) Galkin, M. V.; Samec, J. S. M. Selective route to 2-propenyl aryls directly from wood by a tandem organosolv and palladiumcatalysed transfer hydrogenolysis. ChemSusChem 2014, 7 (8), 21542158.

(39) Zhao, B. C.; Chen, B. Y.; Yang, S.; Yuan, T. Q.; Charlton, A.; Sun, R. C. Structural variation of lignin and lignin-carbohydrate complex in Eucalyptus grandis $\times \mathrm{E}$. urophylla during its growth process. ACS Sustainable Chem. Eng. 2017, 5 (1), 1113-1122.

(40) Huang, X.; Zhu, J.; Korányi, T. I.; Boot, M. D.; Hensen, E. J. M. Effective release of lignin fragments from lignocellulose by lewis acid metal triflates in the lignin-first approach. ChemSusChem 2016, 9 (23), 3261-3267.

(41) Wildschut, J.; Smit, A. T.; Reith, J. H.; Huijgen, W. J. J. Ethanol-based organosolv fractionation of wheat straw for the production of lignin and enzymatically digestible cellulose. Bioresour. Technol. 2013, 135, 58-66.

(42) Renders, T.; Cooreman, E.; Van Den Bosch, S.; Schutyser, W.; Koelewijn, S. F.; Vangeel, T.; Deneyer, A.; Van Den Bossche, G.; Courtin, C. M.; Sels, B. F. Catalytic lignocellulose biorefining in nbutanol/water: a one-pot approach toward phenolics, polyols, and cellulose. Green Chem. 2018, 20 (20), 4607-4619.

(43) Sannigrahi, P.; Ragauskas, A. J.; Miller, S. J. Lignin structural modifications resulting from ethanol organosolv treatment of loblolly pine. Energy Fuels 2010, 24 (1), 683-689.

(44) Shuai, L.; Amiri, M. T.; Questell-Santiago, Y. M.; Héroguel, F.; Li, Y.; Kim, H.; Meilan, R.; Chapple, C.; Ralph, J.; Luterbacher, J. S. Formaldehyde stabilization facilitates lignin monomer production during biomass depolymerization. Science 2016, 354 (6310), 329333.

(45) Sturgeon, M. R.; Kim, S.; Lawrence, K.; Paton, R. S.; Chmely, S. C.; Nimlos, M.; Foust, T. D.; Beckham, G. T. A mechanistic investigation of acid-catalyzed cleavage of aryl-ether linkages: implications for lignin depolymerization in acidic environments. ACS Sustainable Chem. Eng. 2014, 2 (3), 472-485.

(46) Wang, M.; Shi, H.; Camaioni, D. M.; Lercher, J. A. Palladiumcatalyzed hydrolytic cleavage of aromatic C-Obonds. Angew. Chem., Int. Ed. 2017, 56 (8), 2110-2114.

(47) Ma, R.; Hao, W.; Ma, X.; Tian, Y.; Li, Y. Catalytic ethanolysis of kraft lignin into high-value small-molecular chemicals over a nanostructured a-molybdenum carbide catalyst. Angew. Chem., Int. Ed. 2014, 53 (28), 7310-7315.

(48) Ma, Y.; Guan, G.; Phanthong, P.; Li, X.; Cao, J.; Hao, X.; Wang, Z.; Abudula, A. Steam reforming of methanol for hydrogen production over nanostructured wire-like molybdenum carbide catalyst. Int. J. Hydrogen Energy 2014, 39 (33), 18803-18811.

(49) Yokoyama, T. Revisiting the mechanism of $\beta-\mathrm{O}-4$ bond cleavage during acidolysis of lignin part 6: a review. J. Wood Chem. Technol. 2015, 35 (1), 27-42.

(50) Lan, W.; Amiri, M. T.; Hunston, C. M.; Luterbacher, J. S. Protection group effects during $\alpha, \gamma$-diol lignin stabilization promote high-selectivity monomer production. Angew. Chem., Int. Ed. 2018, 57 (5), 1356-1360. 